\title{
Transformation in South Africa and the Kingdom of God
}

\author{
Nico Vorster \\ School for Church Sciences \\ Northwest University (Porchefstroom Campus)
}

\begin{abstract}
The concept of transformation is currently ill defined and often abused for political and ideological ends. This article attempts to provide a sound value base for the concept of transformation from the perspective of the Kingdom of God and to evaluate the current process from this perspective. The task of Christians is to obey the cosmic reign of Christ by disarming the oppressive powers of this world, and by serving the interests of the poor. In the South African context, this means that Christians must engage in the transformation process in order to establish a more just society. However, Christians can only fulfil their calling if they are spiritually transformed themselves. White Christians must realize that the Apartheid system was unjust and that transformation is necessary because the social and economic inequalities in South Africa are systemic in nature. Black Christians must refrain from abusing the transformation process for personal gain. Christians should participate in the transformation process in a critical manner, knowing that old ideologies can easily be replaced by new ideologies, and knowing that the only true Kingdom of Justice will be established by Godself in the coming dispensation.
\end{abstract}

\section{INTRODUCTION}

The term transformation, within the South African political context, describes the process of structural change that is implemented on the political, social and economic levels of South African society. The aim is to eradicate the social and racial inequalities of the past and establish a new society based on the foundational values of the Constitution namely, human dignity, equality and freedom. Transformation is a necessity for the restoration of the dignity of previously disadvantaged groups. Yet the challenges that transformation poses are daunting and the process itself is difficult to manage.

The concept of transformation is currently ill defined and often abused for political and ideological ends. Many whites experience transformation as a 
new form of reversed discrimination that intends to punish them for the past. Few really understand the systemic character of Apartheid, segregation and colonialism and the institutionalised inequalities that it caused. They, therefore, resist transformation in tacit ways. Within previously disadvantaged communities transformation is often misunderstood as a process that unconditionally empowers black people, even if it is at the expense of other groups. Some abuse the notion of transformation for self-enrichment. Others have unrealistic expectations that change will occur overnight.

These misconceptions can deeply affect the new South African democracy in a negative way. If the need for transformation is discarded, the South African democracy will be torn apart by the perpetuation of social inequalities. If managed wrongly, transformation might become a powerful political and ideological tool to oppress minorities and advance black interests in an illegitimate way.

The aim of this article is to provide a Christian perspective on the concept of transformation. Since the kingdom of God is the most comprehensive concept found in the Bible, the current process of transformation will be evaluated from this perspective. This subject can, however, also be studied from the perspective of other biblical perspectives such as man being created in the image of God, the covenant and the New Testament pneumatology.

\section{THE MEANING OF TRANSFORMATION ${ }^{1}$}

In the corporate world a distinction is usually made between first and second order change. In the case of first order change, the system itself, including its basic structure, culture and defining values does not change. The purpose of the intervention is rather to preserve the fundamentals and change the nonfundamentals. Change takes place within the confines of the system itself and is realised in an evolutionary way by means of adaptation, renovation and adjustment (Esterhuyse 2003:2). Second order change is more radical in nature. Its goal is to transform the basic structure, culture, defining values and overall form of an organisation or society. It inevitably breaks the evolutionary chain of development and implements revolutionary change that constitutes a paradigm shift and drastic change in mindset (Esterhuyse 2003:2).

Transformation falls within the category of second order change. It is clear that South Africa needs structural change. Apartheid had a well documented systemic impact on South African society. Black people were

\footnotetext{
${ }^{1}$ For a comprehensive survey on literature regarding church-state relations see Vorster (2003).
} 
subjected to the disownment of their land without compensation, segregation laws, job reservation for whites only, inferior education, cheap labour practises, the impairment of their freedom to move and trade, as well as the denial of all political rights. This created huge social inequalities that will continue to exist if the social conditions of black people are not addressed by positive measures. A mere creation of equal opportunities will not address inequality, because previously disadvantaged groups experience serious backlogs that will make it difficult for them to compete on an equal footing with other groups in a competitive modern environment.

Before evaluating the current process from a Christian perspective, it is necessary to reflect on the biblical view of transformation.

\section{THE KINGDOM OF GOD AND TRANSFORMATION}

The Kingdom of God is the most comprehensive theological concept found in the Bible, because it is not only oriented to the redemption of God's people, but to the self assertion of God in all his works (Ridderbos 1969:23). The word $\beta \alpha \sigma \imath \lambda \imath \varepsilon^{\prime} \alpha$ (kingdom) is a dynamic term that denotes the fact, terrain and manner of God's reign (Van der Walt 1985:9). The kingdom of God is the work of God Himself (Berkhof 1966:161). Its significance for social ethics lies therein that it relates God's reign to the whole of creation, all spheres of human life, to the world and history.

The concept of the Kingdom must not be secularized nor spiritualised. This happens when the dialectical nature of the Kingdom is denied. The Kingdom is a present reality, but also a future reality. It has already penetrated the world in the coming of the person of Jesus Christ. Jesus, therefore, talks about the Kingdom as being "at hand" (Mk 1:15) and "among you" (Lk 17:21). Christians therefore cannot spiritualise the Kingdom as a reality that belongs exclusively to a coming age. To deny the present reality of the Kingdom is to deny the reality of God's reign. Christians have a duty to promote the principles of the Kingdom in all spheres of life. Yet the Kingdom is also a future reality. Jesus teaches his followers to pray for the "coming of the Kingdom" (Mt 6:10), while God himself will fully establish God's Kingdom at the end of times (Lk 13:29; Mt 8:11). The Kingdom is an eschatological reality that finds its true destination not in this world but in the coming age (Jh 18:36). Although the kingdom will only be realized in the coming age Christians ought not to refrain from proclaiming the principles of God's kingdom in this world. 


\subsection{The cosmic nature of the Kingdom of God}

The Bible describes human history as a cosmic war between good and evil. The word cosmos refers in the New Testament to the created world that includes those that rebel against God (cf Floor 1974:23; Rm 1:20, 2 Cor 5:19). The basic message of the Bible is that God created all things good, but that the world fell into the hands of sin and the demonic. God is steadily reclaiming his creation by creating a new world. The resurrection of Christ is the definitive meant of triumph in the struggle against evil (Berkhof 1966:161).

In Jesus Christ God re-establishes his reign on earth. The Kingdom of God is indeed the central theme in Christ's preaching. Jesus starts his preaching with the words: "Repent, for the Kingdom of heaven is near" (cf Mt 4:17; Mk 1:15). He ends his preaching shortly before his ascension by talking to his disciples about the "things of the Kingdom" (Ac 1:3). Jesus' preaching is twice summarised in the gospels of Mathew and Luke as "the gospel of the Kingdom" (Mt 4:23, 9:35; Lk 8:1, 9:11).

The Kingdom is an important theme in Christ's parables. Several parables begin with the words: "The Kingdom of the heaven is like ... (Mt 13; Lk 13; Mk 4). In his parables Christ teaches his disciples about the secrets of the Kingdom (Mt 13:11). It reveals the secrets of God's Kingdom to the children of God, but conceals the secrets of the Kingdom to the world (Mt 13:10-16). The Kingdom is a gift of God that not all people possess (Jh 3:3).

The parables clearly describe God's reign as cosmic in nature. In the parable of the sewer the Kingdom of God is compared with the growing of seed. The growth of the Kingdom cannot be stopped (cf Berkhof 1966:118). Despite setbacks the Kingdom will eventually bear an abundance of fruit. The parables of the mustard seed (Mt 13:31-32), the growing seed (Mk 4:26-29) and the yeast (Mt 13:33) depicts the victorious reality of the Kingdom in a cosmic sense. In the parables of the mustard seed and the growing seed the Kingdom is described as having a small beginning, but eventually it will culminate in a glorious reality that will overshadow all earthly realities. The parable of the yeast depicts the Kingdom as a hidden spiritual reality that will work through in this world, as yeast through dough, until the whole world is under the reign of God. The coming of the Kingdom is depicted as a gradual developing process (Ridderbos 1950:141).

The gospels also relate the miracles to the cosmic reign of Christ. The miracles are mighty works of the Kingdom (Mt 12:28; Lk 11:20), a foretaste of the powers of the new age. In them the power of Christ over the demonic, the truth of his preaching and his Messianic authority becomes visible. Not only are the miracles visible signs of the power of the Kingdom that has broken into 
the world, but they also explain the nature of God's reign. They are indicators of God's love, righteousness and goodness.

The cosmic significance of the work of Christ becomes clear in his calling of the Church. The Church is not the subject of the Kingdom but the object. It is the foothold of the coming of God's Kingdom and at the same time the canal or medium by which the renewing forces of God's Kingdom are going unto and are shaping the world (cf Ridderbos 1979:2). Jesus relates the Church to the Kingdom by giving the Church the keys of the Kingdom (Mt 16:16-20). The keys of the Kingdom denotes the authority to preach the word of God, thereby opening the Kingdom for those that believe and closing it for those that reject the message of the gospel (cf Heidelberg Cathechism, Sunday 31). The fact that Christ gives the keys of the Kingdom not only to the disciples but to the Church is clear from Matthew 18:17 where the Church receives the right to excommunicate sinners. The task of the Church is to administer the Word to the whole world. This is clear from the mission command in Matthew 28: "All authority on heaven and earth has been given to me. Therefore go and make disciples of all the nations, baptising them in the name of the Father of the Son and the Holy Spirit and teach them to obey

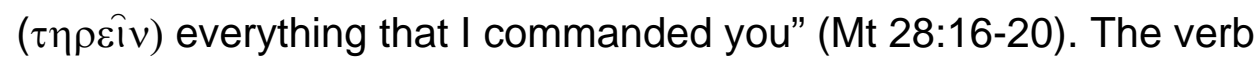
$\tau \eta \rho \varepsilon i v$ refers to a continuous sanctifying role that the Church must play in the world. This is in accordance with the image of the faithful as the salt and light of the earth (cf Mt 5:13-16).

There can be no doubt that the early Church understood Christ's reign as cosmic in nature. In the epistles of Ephesians and Colossians Paul emphasises the cosmic significance of the work of Christ. In Ephesians 1:10 he states that it is the will of God to bring together "all things in heaven and on earth under the head of Christ." In Colossians 1:15 Christ is described not only as the head of the Church, but as the head of "all things, whether things on earth or heaven." It is important to note that Paul speaks of the cosmic Christ within the context of reconciliation. Christ not only came to reconcile the faithful with God, but to reconcile the cosmos with God, by recreating and renewing the creation of God (cf Floor 1974:22).

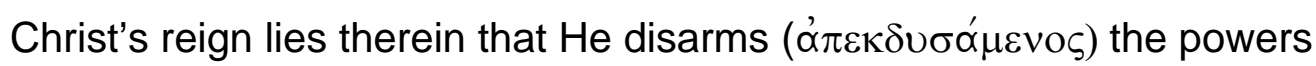

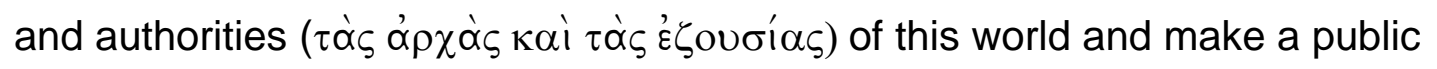

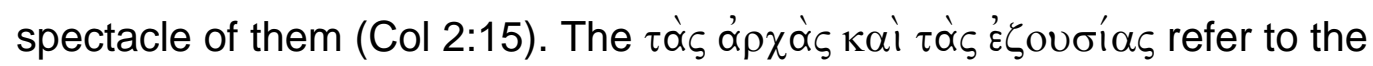
powers which reign the world and bind the souls of men, such as the powers of unbelief, injustice, suppression of the poor, materialism, selfishness, discrimination et cetera (Ridderbos 1979:5). The disarmament does not denote the conversion of these forces but the subjection and pacification thereof (Vorster 2003:395). The sanctifying role of the Church in the world 


\section{Transformation in South Africa and the kingdom of God}

therefore includes obeying the will of God and disarming the powers of this world by using the keys of the Kingdom, namely preaching the Word of God.

The cosmic nature of Christ's reign means that all earthly Kingdoms are related and relativised by the Kingdom of God (Van Wyk, 1992:558). God's reign therefore also has significance for the state. The religious institution of the church reminds the political order of its provisional nature in contrast to the utimacy of God's eschatological future (Pannenberg 1977:101). Barth (1935:21) rightly states that the existence of the state is not separate from the kingdom of Jesus Christ, its foundations and its influence are not autonomous. It is outside the church but not outside the range of Christ's dominion. Christians therefore have the continuous calling to critically assess human structures and to renew them. This does not mean that Christians can expect the state or civil society to gradually become the kingdom of God. The task of the church is to anticipate the kingdom of God (cf Pannenberg 1977:37; Barth 1935:31). The kingdom of God are served when Christians give witness to justice, love, tolerance et cetera (cf Rm 14:17).

Transformation is a continuous process in the life of the Christian. In South Africa Christians will have to engage in the transformation process, because there is a need to replace oppressive structures with just structures. However, Christians have to engage in this process in a critical spirit, since Christians have the task to identify oppressive political ideologies and to demythologise them, thereby disarming the powers of this world.

In order to do this, Christians will have to understand the nature of ideologies. Goudswaard (1984:24) identifies several trademarks of the fully fledged ideology:

- The end has extraordinary significance. People will fight for its goals in excess.

- The end justifies the means. Maximum effectiveness is the test.

- The end distorts genuine norms and values. The norms and values are filled with a new content until they become useful instruments in motivating people to pursue the end.

- The end demands that people and the environment continually adjust to the new laws of the continually developing means. 
- Those who oppose the ideology are characterized as traitors. The ideology also creates scapegoats such as the Jews, Blacks etc, which bear the blame for all the evils that exist in society.

Christians have to be very sensitive for and critical when trademarks of ideological thinking are displayed in the transformation process.

\subsection{The Kingdom of God and repentance}

Transformation on the institutional level without internalisation remains hollow (Esterhuyse 2003:7). Oppressive structures cannot be transformed if the hearts and minds of people don't change, since people are ultimately responsible for the functioning of structures. To change structures the frames of reference, mindsets, beliefs, values and prejudices of people need to change.

The Bible emphasizes the need for repentance and conversion. Repentance is an important precondition for entering the Kingdom of God. This is illustrated in the way that Jesus announces the coming of the Kingdom: "Repent, for the Kingdom of heaven is near" (Mt 4:17).

The New Testament uses two words for repentance, namely

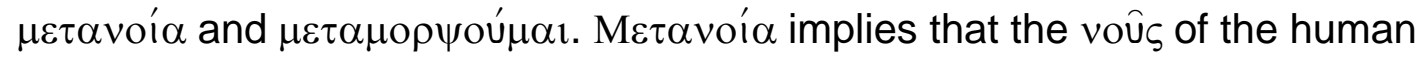
being, that is his heart and mind, must turn back to God. This is only possible through the work of the Holy Spirit (cf Du Plooy 2005:11). Though in English a focal component of repentance is the sorrow or contrition that a person experience because of $\sin$, the emphasis in $\mu \varepsilon \tau \alpha v o$ í is total change both in thought and behaviour, with respect to how one should think and act (Louw \& Nida 1989:510). Jesus uses the word in Mathew 4:17 in connection with the Kingdom of God. True repentance means that the faithful must turn their back on the old aeon, accept Christ as their new King and live according to the rules of Christ.

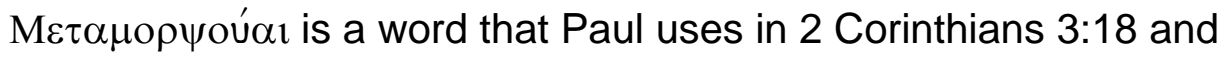
Romans 12:2. It refers to an invisible process that takes place, or begins to take place, in the lives of Christians in the present aeon (cf Du Plooy 2005:11). This process signifies a fundamental change or remodelling in the form and nature of a person (Louw \& Nida 1989:155).

Paul uses $\mu \varepsilon \tau \alpha \mu \rho \rho \psi o u ́ \mu \alpha \imath$ in Romans 12:2 as an imperative: "Do not conform any longer to the pattern of this world, but be transformed by the renewing of your mind." The word conform ( $\sigma \cup \sigma \chi \eta \mu \alpha \tau i \zeta \varepsilon \sigma \theta \varepsilon)$ stands in contrast to $\mu \varepsilon \tau \alpha \mu \rho \rho \psi o u ́ \mu \alpha \iota$ which means to transform. Paul calls upon 


\section{Transformation in South Africa and the kingdom of God}

Christians not to conform but to transform (Du Plooy 2005:11). In 2

Corinthians 3:18 Paul states that this transformation has a particular direction. It entails that the Holy Spirit change the behaviour of Christians so that they can exhibit the image of Christ (2 Cor 3:18). Christ is, according to the New Testament, the perfect image of God. In 2 Corinthians 4:4 Christ is called the

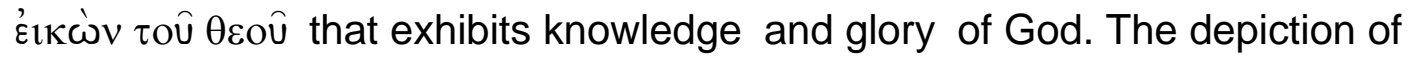

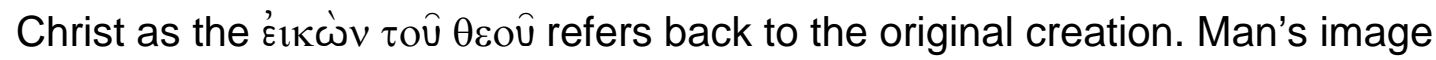
of God has been affected deeply by sin. What man has lost since the fall, he can regain by following the example of Christ who is the perfect image of God.

The following (ǻко in the New Testament. Following Christ is a gift from God. It does not mean that the believer must imitate Christ, but that he must live obedient to Christ, have community with Christ, and participate in the legacy of the salvation work of Christ (cf Vorster 2003:328). The following of Christ is always directed towards fellow human beings. It entails that Christians must act according to the example of Christ ( $\kappa \alpha \theta \omega \varsigma, \omega \varsigma$ ) towards their fellowmen. Like Christ, Christians must exhibit humility (Phlp 2:5), love, tolerance (Col 3:13; Jn 13:34; Mt 5:44) and forgiveness (Eph 4:32) in their human relations. By following Christ the Christian is proclaiming the expectation of the future victory of the righteousness of God over dead and living (Moltmann 1974:177)

In essence transformation is founded by the Bible upon the reconciliatory work of Christ and motivated by the central command of love. Christian love extends to all people, even the enemy (Mt 5:44).

The biblical concept of personal transformation has the following implications for the way that Christians engage in the transformation process in South Africa:

- $\quad$ Christians should emphasise that personal and spiritual transformation ought to coincide with political transformation. The freedom of faith is lived out in political freedom. The freedom of faith therefore urges men on towards liberating actions, because it makes them painfully aware of suffering in situations of exploitation, oppression, alienation and captivity (Moltmann 1974:317).

- $\quad$ The actions of Christians should be motivated by the calling to follow Christ, and not by personal motives. Participation in transformation purely for personal benefit is morally unacceptable. 
- $\quad$ For Christians transformation should have boundaries. As soon as the moral criteria of Scripture are exceeded Christians should start to question the process.

\subsection{The Kingdom of God and the poor}

The gospel of the Kingdom of God is qualified in various passages as the gospel of the poor (Lk 4:18; Mt 11:5; Lk 7:22). The beatitudes of both Mathew and Luke starts by referring to the poor in spirit. They are the true inheritants of the Kingdom of God. According to Ridderbos (1950:170) the expression poor of spirit is derived from the theocratic, covenantal background of the Old Testament. The poor are the socially oppressed who experience injustice from those who enrich themselves. They long for God's liberation and place all their hope for deliverance in God. They are the true bearers of God's promises, because they expect salvation from God and not from the world (Ps 22:27; 37:11; Is 11:4; 29:9). The gospels, in accordance with the Old Testament, qualify the poor in a social and religious ethical sense (Ridderbos 1950:171, Lochmann 1986:66). The poor are those that are now hungry and mourning, because they are the victims of oppression (cf Mt 5:4-6). Their longing for salvation entails a hunger and thirst for righteousness (Mt 5:6). The righteousness for which they long is not forensic righteousness, but the righteousness that flows from the Kingdom of God and the liberation that Christ's reign will bring (Ridderbos 1950:172). Because they expect their deliverance from Christ, they are the true inheritors of the Kingdom of God.

In the gospels the coming of Christ is closely related to deliverance for the poor. Christ has come to bring good news to the poor, to proclaim freedom for prisoners, recovery of sight for the blind, release for the oppressed, and to proclaim the year of the Lord's favour (Lk 4:18-19). True subjection to Christ's reign means that the faithful must care for the physically handicapped and the hungry. Insofar as they care for the poor, they care for Christ Himself: "I was hungry and you gave me food, I was thirsty and you gave me something to drink, I was a stranger and you invited me in, I needed clothes and you clothed me, I was sick and you looked after me, I was in prison and you came to visit me" (Mt 25:34-36).

Care for the poor and the vulnerable is a recurring theme in the Bible. Christians must continually and persistently fight poverty and take care of the poor and needy. It is not that the poor are themselves righteous, but rather that God's righteousness requires justice for the poor (Marshall 1984:108). Poverty creates vicious circles of senselessness and godforsakenness. People become perplexed, disheartened and many men lose all sense of purpose (Moltmann 1974:331). 
Christians in South Africa have a duty to alleviate the huge poverty in South Africa and to address the social inequalities. This ought to be the main focus of the transformation process in South Africa. It is important that the responsibilities of each individual in this regard should not be left to the state and welfare programmes. Poverty alleviation can only succeed if a holistic effort is made by all sectors of society.

\subsection{Conclusion}

The New Testament relates transformation to the coming Kingdom of God. It entails a spiritual conversion that turns away from the old aeon and enters the new aeon by accepting Christ as King and living according to his rules. This spiritual transformation has social implications, since Christ's reign is cosmic in nature. Christians have the duty to promote the principles of God's Kingdom in all spheres of life by disarming oppressive forces and principalities. The poor ought to be the primary focus of any social transformation, since God's righteousness demands justice for the poor.

\section{AN EVALUATION OF TRANSFORMATION IN SOUTH AFRICA}

Transformation in the South African context is a comprehensive process. It coincides with the liberalisation, democratisation and diversification of society (cf Du Plooy 2005:3). Liberalisation entails the abandonment of previous value systems such as a racially based economic and political system and the creation of an open non-sexist and non-racial society which does not discriminate against persons on the basis of race, sex, creed or gender. All citizens are allowed to participate equally and freely in this new society. Social inequalities are addressed by affirmative action. Democratisation denotes the creation of a political system that establishes rules, rights and procedures for citizenship, political participation and accountability. Diversification aims to harmonise the processes of liberalization and democratisation by creating norms and values to manage diversity.

\subsection{Political transformation}

The political transformation of South Africa coincided with the abandonment of the Westminster system (1910-1994) and the establishment of a constitutional state in 1994. In the Westminster system the parliament was sovereign, which meant that parliamentary legislation was not subjected to constitutional measures that protected basic human rights. The Parliament could legislate at 
will, without civil society being able to call upon judicial organs to protect their rights. This lead to the systematic establishment of racist structures in South Africa (cf Basson 1995:17). A constitutional state, in contrast, recognizes the supremacy of the constitution and the rule of law. It provides constitutional protection for basic human freedoms, separates the executive, judicial and legislative powers, and gives civil society the opportunity to participate in legislative processes.

The South African Constitution does not explicitly refer to South Africa as a constitutional state. However, it is clear that the most important elements of a constitutional state are present in the South African Constitution (Venter 1997:81). The 1996-Constitution contains the following principles of a constitutional government:

- The supremacy of the constitution is recognized (art 1[c], 2).

- $\quad$ Fundamental rights are protected by a Bill of Rights (art 8[1]). These rights can only be restricted by the Constitution itself.

- $\quad$ Provision is made for an independent judiciary (art 165).

- The executive, judicial and legislative powers are separated. The executive power belongs to the President, judicial power to an independent judiciary and legislative power to parliament (art 83, 165, $44[4])$.

- $\quad$ Basic democratic principles such as the right to vote, the existence of a national voting list, regular elections, multi-party democracy, accountability of state institutions and political rights are protected (art $1,19)$.

- $\quad$ Provision is made for institutions, such as the Human Rights Commission, that can support the constitutional democracy (art 181 [1]).

Though the political transformation of South Africa is nearly complete there are some areas of concern: 


\section{Transformation in South Africa and the kingdom of God}

- $\quad$ Opposition political parties are weak in relation to the ruling party. The danger exists that South Africa might, in effect, degenerate from a multi-party democracy into a one-party state.

- $\quad$ Politics in South Africa are largely racially determined. Black people vote for black parties and white people for white parties. This is an indication that the country still is racially divided.

- $\quad$ Much still has to be done to create a culture of human rights in South Africa. Criminality has increased quite significantly since 1994. Corruption is a major problem in all spheres of society. The ill administration of justice contributes to the crime problem. It is manifested in an ineffective police force and the low percentage of indictments that result in persecution.

- $\quad$ Service delivery at local government level is poor. Several violent protests against local governments have occurred in recent years because basic services are not delivered.

Since the kingdom of God is characterized by righteousness, Christians have an important task to address racial prejudices, nurture a culture of respect for human rights and to help establish a functional judicial system.

\subsection{Socio-economic transformation}

In contrast to the political and juridical transformation of South Africa, little progress has been made since 1994, in addressing the social and economic inequalities in South Africa.

\subsubsection{Economic strategy}

The democratic government that assumed power in 1994 inherited the most developed economy in Africa, with a modern physical and institutional infrastructure. It also inherited major socio-economic problems, high levels of unemployment, abject poverty of $50 \%$ of the population, sharp inequalities in income and high levels of violence and crime (Terreblanche 2002:4). These socio-economic problems are systemic in nature, since they were mainly caused by the social effects of the oppressive systems of segregation (19101948) and Apartheid (1948-1994).

In 1994 the African National Congress (ANC) published the Reconstruction and Development Programme (RDP) as its manifesto for the 
first election. The RDP stated that the democratic government must play a leading and enabling role in guiding the economy and the market towards reconstruction and development. The government was tasked with integrating economic growth with economic reconstruction and development (Terreblanche 2002:108). The strength of the RDP was that it recognized that the socio-economic problems in South Africa are systemic in nature. The weakness was that the government did not have the capacity to fundamentally restructure the economy. Though the RDP is still officially part of the policy framework of the ANC, the notion of redistribution was dropped in favour of a democratic capitalist approach.

After the election the government committed itself to privatising certain state owned assets in order to attract foreign investment and foreign technology. This policy did not solve the deep seated structural crisis and the unequal distribution of economic power (Terreblanche 2002:437). The government also embarked on a policy of Black Economic Empowerment. It was aimed at restructuring the economy in such a way that the participation of blacks in entrepreneurial and highly skilled jobs would increase (Terreblanche 2002:437). The BEEcom report of 2001 noted that this policy had limited success and pleaded for a nationally integrated black economic empowerment strategy. It also set targets for black participation in the economy such as that black companies/individuals should own at least $30 \%$ of productive land, have at least a $25 \%$ equity ownership in each sector of the economy, including companies listed on the JSE, secure at least $30 \%$ ownership of privatised entities and $50 \%$ of procurement contracts entered into by government on all levels, comprise at least $40 \%$ of the boards of directors of listed companies and occupy $40 \%$ of executive and other senior management positions in the private sector and make up at least $50 \%$ of borrowers on the loan books of national development finance institutions (2001:8-9). A new report - Indirect Black Economic Empowerment (BEE) through the JSE: Is South Africa making progress? - suggests that black ownership of the JSE stands at $16 \%$ which is much higher than the generally assumed levels of less than 5\%. Yet the report also finds that South Africa is not making real progress on the empowerment front, since a large amount of black shareholding is indirect based on pensionfund membership, the JSElisted wealth is concentrated in the hands of fewer individuals, and the value of assets on a per capita basis for the black population has barely increased (cf Steyn 2005:10-12). Although the policy of Black Economic Empowerment is important, it still does not address the poverty of the masses.

In 1996 the Growth, Employment and Redistribution (GEAR) strategy was announced. It stressed the need for market led growth, fiscal and 


\section{Transformation in South Africa and the kingdom of God}

monetary discipline and investor confidence (Terreblanche 2002:115). The GEAR strategy drastically reduced the role of the government in the economy. In order to encourage investor confidence the government had to refrain from economic intervention. The GEAR programme aimed at creating maximal growth. This would lead to more jobs that would empower the poor (the socalled trickle down effect).

The abovementioned methods have not been successful. Statistics show that the gap between rich and poor has widened since 1994. According to Terreblanche (2002:31) structural unemployment has increased from 4.8 million in 1995 to 6.8 million in 2001 and the percentage of unemployed has increased from 36.1 percent in 1995 to 45.8 percent in 2001 . While the income of richer income groups, including the richer $25 \%$ of black people, has increased considerably, the per capita income of the poorer two thirds of the population (mainly blacks and coloureds) has declined further. The result is that the South African society is as socially stratified as ever before. Not so much in terms of race, since a significant part of the wealthy class consists of blacks, but in terms of class. This situation has not improved much since 2001.

Several reasons can be identified as the cause of this: a) growth has been lower than expected, b) the growth that was achieved has benefited the rich but not the poor c) HIVIAIDS has a destructive effect on the productivity of the workforce and disrupts social structures, d) the free market tends to benefit those that are capable of competing and marginalise those that do not, e) social inequalities remain deeply entrenched making it difficult for the poor to participate in a globalised modern economy, f) the population growth of the poorest half of the population is much higher than that of the wealthier segment, g) the capacity of public departments and local government to address poverty are weak because of deficiencies and incapability, $h$ ) the removal of farmers subsidies and labour reforms have led to major job losses g) globalisation increases inequality.

The trickle-down philosophy must be questioned from a Christian ethical perspective. The first goal of an economic policy, especially in a classdivided country such as South Africa, should not be to create prosperity in the hope that it will then take care of the poor. The falsity of this argument can be seen in the fact that economic growth in South Africa has mainly benefited the rich, while the poor are still marginalised, because they don't have the capacity to participate in a globalised modern economy. The point of departure should rather be to act upon poverty first (cf Marshall 1984:110). This means that government must take the lead in providing resources and new beginnings for the poor. Without aggressive redistributive intervention by 
the government, the poorest half of the population will remain trapped in a situation of pauperisation (cf Terreblanche 2002:39). Such measures might include the following: to counteract the strong tendency towards large capital intensive enterprises, as well as the government's tendency to detach themselves from the unskilled black labour force and the black consumer market; to improve the amounts spend on skills and training in the private and public sectors; to protect local markets and agriculture against cheap imports; to promote investment in black urban areas; to revise labour laws, such as laws on minimum wages that lead to job losses; to counteract the tendency in the productive sector to become more capital intensive and less labour intensive; to subsidise employment in labour-intensive economic activities and to take the lead in job creation programs (cf also Terreblanche 2002:463-466).

It is important that all South Africans should concern themselves with the poor. This might imply a willingness of the have's to pay higher taxes in order to redistribute more wealth to the have-nots. This paradigm shift will only take place if white people are taught to understand the systemic nature of economic inequality in South Africa, and rich black people are taught not to forget their brothers and sisters in need. The Church has an important role to play in this regard.

\subsubsection{Affirmative action}

The South African Constitution emphasises the value of equality, in the light of South Africa's legacy of inequality. Equality is one of the foundational values in the South African Constitution (art 1(a)). Constitutional jurisprudence usually distinguishes between two forms of equality namely, formal and substantive equality.

Formal equality assumes that all people are equal bearers of rights within a judicial system. Equality is achieved by recognizing the equal rights of all, by way of non-preferential treatment. The background and special circumstances of people are not taken into account. The formal notion of equality is not interested in structural differences in equality and will not implement affirmative action measures. Substantive equality, in contrast, take cognisance of the social and economic circumstances that cause inequality between people and groups of people. It examines underlying conditions that contribute to differences in the means to compete, and is therefore more inclined to implement affirmative action measures that take positive steps in order to eradicate institutionalised inequalities in society (Vorster 2003:261; Pretorius 2001:17).

The South African Constitution clearly makes provision for a substantive notion of equality. Article 9(2) obliges the State to take legislative 
and other measures in order to protect or advance persons or categories of persons that were disadvantaged by unfair discrimination in the past. This understanding of article 9 of the Constitution has been confirmed by the Constitutional Court in National Coalition for gay and lesbian equality $v$ Minister of Justice and others [par 62]: "we have encapsulated the notion of substantive as opposed to formal equality. Section 9 of the 1996-Constitution, like its predecessor, clearly contemplates both substantial and remedial equality".

Since the acceptance of the Constitution in 1996, several acts were enacted to implement article 9(2) of the Constitution. The Employment Equity Act (55/98) was enacted in 1998 to provide for employment equity. It seeks to implement the broad equality objectives of the Constitution in the field of employment by prohibiting all forms of unfair discrimination in the workplace and, in addition, requiring all so-called designated employers ${ }^{2}$ to institute affirmative action measures in favour of black people, women and people with disabilities (cf article 2, Pretorius 2001:13). According to article 15(2) the affirmative action measures that must be taken include:

a) measures to identify and eliminate employment barriers, including unfair discrimination, which adversely affect people from designated groups;

b) measures designed to further diversity in the workplace;

c) making reasonable accommodation for people from designated groups in order to ensure that they enjoy equal opportunities and are equitably represented in the workforce of a designated employer;

d) i) measures to ensure the equitable representation of suitably qualified people $^{3}$ from designated groups in all occupational categories and levels in the workforce; and

ii) to retain and develop people from designated groups and implement appropriate training measures, including measures providing for skills development.

\footnotetext{
${ }^{2}$ Article 28 defines designated employers as: a) An employer who employs 50 or more employees, b) an employer who employs less than 50 employees but has a total annual turnover equal or above the turnover of a small business, c) a municipality, d) an organ of state as defined in article 239 of the constitution, e) an employer bound by a collective agreement in terms of article 23 or 31 of the Labour Relations Act.

${ }^{3}$ It is important to note that in determining whether the workforce of an employee are representative the availability of suitably qualified persons are taken into account.
} 
In determining whether an employer has complied with the provisions of the act, the Director General can take a number of factors into account, including the demographic profile of the national and regional economically active population, the pool of suitably qualified persons from designated groups, from which the employer may reasonably expect to promote or appoint employees, the financial factors relevant to the sector in which the employee operates, the present and anticipated economic and financial circumstances of the employer, the number of present and planned vacancies that exist in various categories and levels and the employer's labour turnover (Dupper 2004:192)

A second act that is central to the affirmative action program, is the Act on the Promotion of Equality and Prevention of Unfair Discrimination (4/2000). This act aims at preventing unfair discrimination, providing restitution for victims of unfair discrimination and promoting substantive equality. Article 7 prohibits unfair discrimination on the basis of race, by distinguishing between five categories of unfair discrimination. This pattern is repeated in articles 8 and 9 that prohibit discrimination on the basis of gender and disability. Chapter 3 makes provision for steps and consideration in determining whether a form of discrimination is fair or unfair, while Chapter 4 makes provision for judicial mechanisms to adjudicate cases that pertain to unfair discrimination.

According to Venter (2004:15-16) it is an open question whether the abovementioned laws only elaborate on constitutional requirements, or whether they, in some instances contradict the Constitution. Article 6(2) of the Employment Equity Act states that it is not unfair discrimination to take affirmative action measures consistent with the purposes of the act. It furthermore allows for preferential treatment and numerical goals in article 15(3). The Constitution, however, prohibits any form of unfair discrimination. Affirmative action cannot be a defence against unfair discrimination. The Act on the Promotion and Prevention of Unfair Discrimination, at the same time, elaborates on the Constitution's definition of affirmative action in article 14(1): "It is not unfair discrimination to take measures designed to protect or advance persons or categories of persons disadvantaged by unfair discrimination or the members of such groups or categories of persons" (own italics). The implication is clearly that persons that experienced no unfair discrimination in the past, are also eligible for preferential treatment, simply because they belong to a designated group. According to Venter (2004:15) this is an unconstitutional elaboration because article 9(2) of the Constitution states that the aim of legislation should be to promote the achievement of equality. The achievement of equality is not promoted by preferential treatment of people who were not discriminated against. 
It is clear that affirmative action legislation can easily become a new tool of oppression. This happens when restorative justice is applied to such a degree, that the value of equality itself is endangered.

In practice, affirmative action laws have not succeeded in addressing inequalities. Though the Employment Equity Act and the Act on the Promotion and Prevention of Unfair discrimination have helped to address the legacy of Apartheid and racism in the workplace they have benefited only the aspiring African petit bourgeois, who have jobs and are members of trade unions. The interests of a relatively small group are advanced by these laws. Legislation alone cannot rectify the plight of the poorest half of the population (cf Terreblanche 2002:47). The following problems arise in the implementation of affirmative action:

- It reifies racial consciousness, since it works in racial categories. Racial prejudices are further exacerbated, in practice, by the fact that affirmative action measures predominantly favours Blacks; while Indians, Coloureds, women and disabled people don't receive the same amount of preferential treatment.

- It has contributed to a significant rise in labour costs, leading to employers cutting their labour force (Terreblanche 2002:120). At the same time affirmative action lead to the loss of skills, since many well trained and skilled white people leave the country to seek better opportunities elsewhere (cf Black 2002:1159).

- It affects the affectivity of the workforce, since many affirmative action appointees are hastily appointed for reasons of political correctness, without the employers making sure that they possess the necessary skills for their jobs.

- It has lead to careerism and opportunism among those advantaged by affirmative action. Since suitably qualified persons from designated groups are numbered, companies and institutions are willing to pay them big amounts of money, in order to rectify the racial composition of their workforce.

- $\quad$ The persons who are affected the most by affirmative action are young white people who were not responsible for the Apartheid system. Though it can still be argued that they benefit from the privileges of 
their parents, this argument will not be valid for much longer. A sunset clause is therefore needed to provide a cut-off date for the process.

- A relatively small portion of society (5\%) carries the costs of redress to the disadvantaged (Dupper 2004:200). Since affirmative action in South Africa favours the majority and disadvantages the minority, there is a danger that affirmative action might become entrenched, since minorities are overwhelmed by the political power of the majority.

- $\quad$ Those who suffered the most under Apartheid are seldom those who benefit the most by affirmative action. Since affirmative action laws focuses on groups and not the circumstances of individuals, individuals who are not needy, and did not experience the same amount of discrimination than others, will receive benefits at the expense of those that need compensation the most (cf Dupper 2004:204).

- $\quad$ Affirmative action leads to the stigmatisation of those that are advantaged by the process, since they are seen by colleagues as tokens.

Though affirmative action measures create definite problems, there is no denial in that affirmative action is needed in order to create a normal society. If the injustices of the past are not rectified, disorder and conflict will continue to characterize South African society. The following guidelines can be offered from a Christian perspective for a just process of affirmative action: a) restorative justice must be implemented in a way that does not endanger the value of equality itself, b) affirmative action must be implemented in a manner that promotes reconciliation, not divide people among racial lines, c) alternative measures of compensation, such as cash payments, may be considered in order to spread the costs of the process more fairly among everyone and lighten the burden on young white males, d) a sunset clause must be implemented to ensure that affirmative action does not become an entrenched policy, e) intensive training programs must be implemented to develop skills, f) merit should still play an important role in appointments $g$ ) the process should not be unduly forced or hastened, since this create more problems than it solves.

\subsubsection{Land reform}

Many black communities were dispossessed of their land during the colonial, segregation and Apartheid periods. The most conspicuous form of land 
removal took place with the acceptance of Land Act (27/1913). It created native reserves, leading to mass removals of black people from their land. Article 25 of the South African Constitution, therefore, obliges the State to implement measures of land reform. The Land Reform process has two components, namely restitution for those persons who were dispossessed of their land after June 1913, and land redistribution. Since 1999 good progress has been made with the completion of land claims (Fouche 2004:16). However, the land redistribution process are progressing at too a slow pace. The government has committed itself to redistribute $30 \%$ of all agricultural land to black owners before 2014 . Thus far only $4.3 \%$ land has been redistributed. In the meantime, many of the agricultural projects on this redistributed land has failed (Moos 2005:14). Various factors play a role in the slow progress of land reform:

- The State has not developed a comprehensive strategy to deal with land reform.

- Only $0.79 \%$ (R1,79 milliard) of the national budget is allocated for land reform. Though a lot of agricultural land is available to be sold the State does not have the funds to buy it. The State will have to spend at least thirty milliard rand to buy $30 \%$ of agricultural land (Fouche 2004:16)

- $\quad$ Poor communication between affected parties, unnecessary burocratic processes, poor coordination between state departments and administrative incompetence within the Department of Land Affairs are contributing to slow reforms (Fouche 2004:16).

- $\quad$ The economic importance of agriculture has declined. Agriculture can only provide a sustainable income only for a limited amount of people (Moos 2005:14).

- $\quad$ Commercial agriculture demands training and special skills. It will take time for new farmers to acquire the necessary skills.

- Aspirant farmers find it difficult to attain loans from banks to create the necessary infrastructure to farm.

The State is currently considering more stringent measures to quicken land reform. These include the expropriation of land according to production value 
and not market value, and higher taxes that will force farmers to get rid of land that is not utilised. These measures could impoverish current farmers, since they lose their jobs and source of income when their land is expropriated. The compensation that the proposed expropriations will provide, will in many instances only be adequate to repay debts.

The following ethical guidelines for the Land reform process can be given from a Christian perspective:

- $\quad$ Injustices of the past must be addressed in a way that serves reconciliation. The current proposed methods of expropriation are unjust and will lead to greater animosity in the community at large.

- $\quad$ Restitution should start with government properties.

- $\quad$ The government must invest a larger part of the national budget in land reform. Enough land is available that can be redistributed on the basis of willing seller-buyer.

- $\quad$ Present land owners cannot be held responsible for injustices of the past. The whole society should take collective responsibility in rectifying past injustices. This must be done by providing fair compensation to those that were dispossessed in the past, and those that lose their current means of survival.

- New owners should be trained to utilise agricultural land responsibly.

\section{CONCLUSION}

The task of Christians is to obey the cosmic reign of Christ, by disarming the oppressive powers of this world, and by serving the interests of the poor. In the South African context, this means that Christians must engage in the transformation process in order to establish a more just society. Christians will have to emphasise the need that political transformation must coincide with a spiritual transformation. Whites must realize that the Apartheid system was unjust and that transformation is necessary because the social and economic inequalities in South Africa are systemic in nature. Blacks must refrain from abusing the transformation process for personal gain. Christians ought to participate in the transformation process in a critical manner, knowing that old ideologies can easily be replaced by new ideologies, and that the only true Kingdom of justice will be established by God Himself in the coming age. 


\section{Works consulted}

Barth, K 1935. The word of God and the word of man, tr by D Norton, London: Hockler \& Stoughton.

Basson, D 1995. South Africa's interim constitution: Text and notes, rev ed. Juta: Kenwyn.

BEECom. 2001. A National integrated black economic empowerment strategy. Johannesburg: Scotaville.

Berkhof, H 1966. Christus de zin der geschiedenis. Nijkerk: G F Callenbach.

Black, P A 2002. On the case for Black economic empowerment in South Africa. Die Suid-Afrikaanse Tydskrif vir Ekonomie 70(8), 1148-1162.

Dupper, 0 2004. In defence of affirmative action in South Africa. The South African Law Journal 121(1), 187-215.

Du Plooy, A D le R 2005. Transformasie: 'n Kritiese perspektief vanuit die teologie. Paper delivered on the $17^{\text {th }}$ March at the Potchefstroom Campus Forum in Potchefstroom, South Africa.

Esterhuyse, W P 2003. The challenge of transformation: Breaking the barriers. South African Journal of Business and Management 34(3), 1-8.

Floor, L 1974. Die koninkryk van God en die vernuwing van die maatskappy. Pretoria: RGN. (Publikasie reeks, 50.)

Fouche, J 2004. Grondhervorming: Voorstelle gedoen. Landbouweekblad, 16 November.

Goudzwaard, B 1984. Idols of our time. Illinois, IL: Intervarsity Press.

Lochmann, J M 1986. Church and world in the light of the Kingdom, in Limouris, G (ed), Church, world and Kingdom, 58-73. Geneva: World Council of Churches.

Louw, J P \& Nida, E A (eds) 1989. Greek-English Lexicon of the New Testament based on semantic domains, Vol 1\&2. New York: United Bible Societies.

Marshall, P 1984. Thine is the Kingdom. London: Marshall, Morgan \& Scott.

Moos, A 2005. Grond: Belowe minder, doen meer. Landbouweekblad, 14 Junie.

Moltmann, J 1974. The crucified God: The cross of Christ as the foundation and critisism of Christian theology, tr by R A Wilson \& J Bowden. London: SCM.

Pannenberg, W 1977. Human nature, election and history. Philadelphia, PA: Westminster.

Pretorius, J L 2001. Legal evaluation of affirmative action in South Africa. Journal for Juridical Science 26(3), 12-28.

Ridderbos, H 1950. De komst van het koninkrijk. Kampen: Kok.

Ridderbos, H 1969. The coming of the Kingdom, tr by $\mathrm{H}$ de Jongste. Philadelphia, PA: Presbiterian and Reformed Publishing.

Ridderbos, H 1979. Church, world and kingdom. Instituut vir Reformatoriese Studies, Studiestuk 141.

South Africa, 1913. Land Act no 27 of 1913. State Press: Pretoria.

South Africa, 1996. Constitution of the Republic of South Africa as adopted by the Constitutional Assembly on 8 May 1996 and as amended on 11 October 1996. (B34B-96.)

South Africa, 1998. Employment Equity Act no 55 of 1998. Pretoria: State Press.

South Africa, 2002. Act on the Promotion of Equality and Prevention of Unfair discrimination no 4 of 2000. Pretoria: State Press. 
Steyn, G 2005. New BEE balance. Finance Week, April, 10-12.

Terreblanche, S 2002. A history of inequality in South Africa, 1652-2002.

Pietermaritzburg: University of Natal Press.

Van der Walt, B J 1985. Die koninkryk van God in die Bybel. Instituut vir Reformatoriese studies, Studiestuk nr 217.

Van Wyk, J H 1992. Predikant en politiek. In die Skriflig 26(4), 551-562.

Venter, F 2004. Die beperkings van regstellende gelykheid. Potchefstroom Electronic Law Journal 1, 1-26.

Vorster, N 2003. Kerk en menseregte in Suid-Afrika. Potchefstroom: PSP.

\section{Court cases}

NATIONAL COALITION FOR GAY AND LESBIAN EQUALITY AND OTHERS

VERSUS MINISTER OF JUSTICE AND OTHERS 1998 (12) BCLR1517 (CC). 